\title{
Realism and Analysis within Public Law
}

\section{Barbara Mauthe}

Lecturer in Law, Lancaster University

b.mauthe@lancaster.ac.uk

\section{Thomas E. Webb}

Academic Fellow, Lancaster University

t.webb@lancaster.ac.uk

The aim of this paper is to explore assertions of realism in public law. Given the breadth of this goal it is proposed to confine the examination to one particular area of public law, that of constitutionalism, and three particular theorists, namely Allan ${ }^{1}$, Loughlin $^{2}$ and Walker ${ }^{3}$. All three theorists assert that their explanation of

1 Generally see T.R.S. Allan, Law, Liberty, and Justice: The Legal Foundations of British Constitutionalism (Oxford: Clarendon OUP, 1993); 'Review: Procedural Fairness and the Duty of Respect' (1998) 18(3)(Aut) Oxford Journal of Legal Studies 497-515; 'The Rule of Law as the Foundation of Judicial Review' in C. Forsyth (ed.) Judicial Review and the Constitution (Oxford: Hart Publishing, 2000), pages 415-419; Constitutional Justice: A Liberal Theory of the Rule of Law (Oxford: Oxford University Press, 2001); 'The Constitutional Foundations of Judicial Review: Conceptual Conundrum or Interpretative Inquiry?' (2002) 61(1) Cambridge Law Journal 87-125; 'Constitutional Dialogue and the Justification of Judicial Review ‘(2003) 23(4) Oxford Journal of Legal Studies 563-584; 'Legislative Supremacy and Legislative Intention: Interpretation, Meaning and Authority' (2004) 63(3) Cambridge Law Journal 685-711; 'Human Rights and Judicial Review: A Critique of 'Due Deference' (2006) 65(3) Cambridge Journal of Legal Studies 671-695.

2 Generally see M. Loughlin, Sword \& Scales: An Examination of the Relationship Between Law and Politics (Oxford: Hart Publishing, 2000); The Idea of 
constitutionalism represents a form of reality. Loughlin, for example, argues that his understanding of constitutional reality can be found in 'the structure of beliefs that constitute the idea of public law' along with the 'set of ideas which we are obliged to

Public Law (Oxford: Oxford University Press, 2003); 'Ten Tenets of Sovereignty' in N. Walker (ed.), Sovereignty in Transition (Oxford: Hart Publishing, 2003) pages 5586; 'Constitutional Theory: A 25 ${ }^{\text {th }}$ Anniversary Essay' (2005) 25(2) Oxford Journal of Legal Studies 183-202; 'Reflections on The Idea of Public Law' in E.A. Christodoulidis and S. Tierney (eds.) Public Law and Politics (Aldershot: Ashgate Publishing, 2008) pages 47-68; 'In Defence of Staatslehre' (2009) 48(1) Der Staat 128; 'What is Constitutionalisation' in P. Dobner and M. Loughlin (eds.) The Twilight of Constitutionalism? (Oxford: Oxford University Press, 2010) pages 47-69; The Foundations of Public Law (Oxford: Oxford University Press, 2010).

3 Generally see N. Walker, 'The Idea of Constitutional Pluralism' (2002) 65(3) The Modern Law Review 317-359; 'Late Sovereignty in the European Union' in N. Walker (ed.), Sovereignty in Transition (Oxford: Hart Publishing, 2003) pages 3-32; 'Postnational Constitutionalism and the Problem of Translation' in J.H.H. Weiler and M. Wind (eds.) European Constitutionalism Beyond the State (Cambridge: Cambridge University Press, 2003) pages 27-54; 'The Variety of Sovereignty' in R. Adler-Nissen (ed.), Sovereignty Games: Instrumentalising State Sovereignty in Europe and Beyond (UK: Palgrave Macmillan, 2008) pages 21-32; 'Taking Constitutionalism Beyond the State' (2008) 56(3) Political Studies 519-543; 'Constitutionalism and the Incompleteness of Democracy: An Iterative Relationship' (2010) 39(3) Rechtsfilosofie \& Rechtstheorie 206-233; 'Beyond the Holistic Constitution?' in P. Dobner and M. Loughlin (eds.) The Twilight of Constitutionalism? (Oxford: Oxford University Press, 2010) pages 291-308. 
accept' combined with the 'basic concepts which are pre-supposed' when we 'speak and act in public law terms'. ${ }^{4}$ Loughlin observations are represented as a true account of 'the character of actually existing constitutional arrangements'. ${ }^{5}$ Walker presents quite a different view of reality, one that consists of multiple constitutional authority formations and interpretations ${ }^{6}$ which are spread globally in 'a complex and evershifting mosaic of the new and the old, the emergent and the mature' ${ }^{7}$ Unlike Loughlin and Walker, Allan is less concerned with representing the 'big picture' of the theory of constitutionalism. For Allan constitutionalism is centred on judicial activism which is in turn based on a theory of the rule of law, derived from the common law tradition. It is acknowledged that there are many other public lawyers who write on constitutionalism but, as illustrated above, Allan, Loughlin and Walker's represent a diverse range of analyses on the topic. This then raises the question: how can such diverse, possibly even incompatible analyses, all represent reality?

In order to answer this question the paper will begin by considering how to test for realism in public law and then examine representations of realism in order to

4 M. Loughlin, 'Reflections on The Idea of Public Law' in E.A. Christodoulidis and S. Tierney (eds) Public Law \& Politics (Aldershot: Ashgate Publishing, 2008), page 64 .

5 M. Loughlin, 'Constitutional Theory: A $25^{\text {th }}$ Anniversary Essay' (2005) 25(2) Oxford Journal of Legal Studies 183-202 at 186.

${ }^{6}$ N. Walker, 'The Idea of Constitutional Pluralism' (2002) 65(3) The Modern Law Review 317-359 at 354 .

${ }^{7}$ N. Walker, 'The Idea of Constitutional Pluralism' (2002) 65(3) The Modern Law Review $317-359$ at 357. 
identify key features of realism analysis. The writings of Allan, Loughlin and Walker in relation to constitutionalism will then be explored with reference to the identified features. The paper will conclude by offering a number of comments on realism and analysis in public law.

\section{The Testing of Realism within Public Law Analysis}

The assertion of realism is a feature to be found in all areas of academia thus making it one of the most common and possibly even the most overused terms to be found in scholarly discourse. Simplistically, realism refers to the totality or completeness of all real things. As a philosophical approach realism is about reality. It is an approach that can be found in such diverse disciplines as law, sociology, literature, history, science, etc. In addition to the contextual placement of realism there is also the matter of varieties of realism along with levels and dimensions of realism to consider.

Given the wide range of assertions, characteristics and definitions to be found in respect of realism it is proposed to focus on two specific forms of realism, that of legal realism and scientific realism. The reasons for the selection of these particular forms of realism are as follows. Legal realism is a school of thought within jurisprudence and is generally regarded as a key topic within a jurisprudence course. A fact evidenced by its inclusion in many key/core textbooks available for the study of jurisprudence at undergraduate level. This would indicate that there should be some discoverable commonality between realism-claiming assertions within law in general and assertions of realism within a particular domain of law, that of public law and thereby the theory of constitutionalism. Conversely, scientific realism is external to law and represents a body of knowledge that possesses limited attraction to 
lawyers. This does not indicate that scientific analysis is unknown within legal analysis. There is, for example, the application of theories of quantum mechanics and relativity to constitutional law $^{8}$ along with the application of chaos theory to jurisprudence. ${ }^{9}$ More recently there has been the consideration of complexity theory ${ }^{10}$ along with a general consideration of scientific methods as the basis for the study of law. ${ }^{11}$ These studies indicate that it is possible for lawyers to draw upon scientific analysis. The use of scientific realism for the purposes of this paper is therefore acceptable. It represents an approach that it is neither novel nor unique but just different, a facet which should not be excluded when testing any forms of analytical statement.

Accordingly, it is proposed to juxtapose legal realism, a realm where there is a high expectation in terms of the discovery of common features, with scientific realism, a realm where there is a low expectation as to the discovery of shared features. From such a juxtaposition it should be possible to identify features with sufficient strength of commonality from which to test statements of realism within public law. Of course, it could be argued the juxtaposition represents a 'mere contrivance' and the resulting analysis is likely to lack vigour. This criticism is

8 See L.H. Tribe, 'The Curvature of Constitutional Space: What Lawyers Can Learn From Modern Physics' (1989) 103 Harvard Law Review 1-39.

${ }^{9}$ See A.W. Hayes, 'An Introduction to Chaos and Law' (1991-92) 60 University of Missouri Kansas City Law Review 751-774.

10 See J.B. Ruhl, 'Law's Complexity: A Primer' (2008) 24 Georgia State University Law Review 885-911.

11 See S. Coyle and G. Pavlakos (eds.) Jurisprudence or Legal Science (Oxford: Hart Publishing, 2005). 
acknowledged but, given the absence of an explicit or even tentative premise from which to evaluate 'realism' within public law, it is countered that the approach represents sound methodology.

\section{Juxtaposing Legal Realism and Scientific Realism}

Before juxtaposing facets of legal realism with scientific realism, it is first necessary to offer a brief descriptive account of the two approaches. Not only will this provide the reader with some understanding of these terms, legal realism and scientific realism, but it will also assist in the identification of similarities.

\section{Legal Realism}

Legal realism is an approach to legal analysis that seeks to abandon the metaphysical approach to law in favour of analysis that is premised on life and experience. There are two identifiable schools of legal realism, the American and the Scandinavian. For the purposes of this paper it is proposed to draw on the key themes outlined by the American school of legal realism. ${ }^{12}$ Within this school there is much diversity amongst those who claim to be 'legal realists' but it is possible to identify three key features. These are the attack on formalism, the indeterminacy of law and legal instrumentalism.

12 Although Scandinavian legal realism emerged at the same time as that of American legal realism its influence was limited. The works of its key writers are rarely referenced or applied today even within Scandinavia. 
The attack on formalism relates to the limited material base from which legal analysis is conducted. Sources, such as case law, form the basis from which legal principles and doctrines are 'discovered' much in the way that scientists discover their principles within the confines of a laboratory. ${ }^{13}$ Legal realists sought to challenge the scientific pretensions of 'legal science' where an argument is presented as is if the conclusion can be deductively induced from an indeterminate premise. Legal realists argued that this classical approach, which is represented as 'mechanical jurisprudence', ${ }^{14}$ fails to take into consideration real life/world conditions or consequences.

The indeterminacy of law is closely related to the attack on formalism. Legal realists argue that judicial decisions are often determined by factors other than legal rules, principles or norms. Judges 'follow their instincts' and make 'sham references to rules of law', are generally 'unaware of what they are doing' and persist in foolishly 'believing 'that they are being obedient to precedent' ${ }^{15}$

Legal instrumentalism is where the law is viewed as a tool to achieve certain social goals and balance competing interests within society. Legal realists regard the role of

13 See Christopher Columbus Langdale, "Preface" in A Selection of Cases on the Law of Contract (1871) quoted in W. Twining, Karl Llewellyn and the Realist Movement (University of Okalahoma Press: Norman, Okalahoma, 1985) page 11. See also J. Dickinson, 'The Law Behind Law’ (1929) 29 Columbia Law Review 113146 at $141-46$.

14 See R. Pound, 'Mechanical Jurisprudence' (1908) 8 Columbia Law Review 605-623.

15 B. Kaplan, 'Do Indeterminate Appeal Courts Have a Law making Function?' (1985) 70 Massachusetts Law Review 10 at 10. 
the judge as being to focus on the future social and economic consequences of their decisions rather than the rights and obligations created by past precedents or even statutory enactments. ${ }^{16}$

There are, of course, problems and criticisms of legal realism. The problems relate to its decline as an approach to legal analysis after the Second World War, largely as a consequence of its cynical and nihilistic character. Its censure of judges and law making did not fit comfortably in an era that sought to criminalise the past activities of fascism and incorporate the perceived threat of communism. ${ }^{17}$ Criticisms of legal realism relate to its perception as the nature of law and the role of the judge. Dworkin is highly critical of legal realism labelling its results orientated, policy based approach to judicial decision making as 'pragmatism'. ${ }^{18}$ For Dworkin the law cannot be based on arbitrary distinctions as this would undermine the very meaning and purpose of the law. Other criticisms relate to the absence of a coherent methodology and theoretical premise. Posner, for example, argued that legal realists 'gave empirical research rather a bad name amongst legal academies' and that as a movement 'it illustrated the futility of empirical investigation severed from a theoretical framework'. ${ }^{19}$

16 Generally see K.N. Llewellyn, 'A Realistic Jurisprudence - The Next Step' (1930) 30 Columbia Law Review 431-465; The Bramble Bush (New York: Oceana Publication Inc., 1930).

17 Generally see E.A. Purcell, The Crisis of Democratic Theory: Scientific Naturalism \& the Problem of Value (University Press of Kentucky: Lexington, 1973). 18 R. Dworkin, Laws Empire (Harvard University Press: Cambridge, Mass., 1986). 19 See R.A. Posner, Overcoming Law (Cambridge, Massachusetts: Harvard University Press, 1995), page 19. 
A further criticism, and one that is pertinent to this paper, is that legal realists draw heavily on commercial law and not constitutional law. How then can such an approach be used to test assertions of realism in the context of public law? This criticism was contested, most notably by Hale, who was derisive of the public-private distinction. ${ }^{20}$ Hale argued that it was the decisions of governments that created and structured the 'private sphere' even by way of its non-interference and therefore the division was an artefact of government. ${ }^{21}$ This view has been asserted as representing a non-sequitur. ${ }^{22}$ It is argued that it does not matter if there is a private realm or a public realm of law, what matters is the fact that a division exists. If the underlying normative reasons for the division are sound then these provide sufficient reason for the absence of interference by governments in the private realm. ${ }^{23}$ It therefore follows that to dismiss the applicability of legal realism to constitutional analysis is also unsound since the normative reasons for the separation, however formally or informally the separation is determined, are part of the justification for the existence of both the private and public realm. In other words, whilst the origins of legal

20 See R. Hale, 'Coercion and Distribution in a Supposedly Non-Coercive State' (1923) 38(3) Political Science Quarterly 470-494. Also see also M.R. Cohen, 'Property and Sovereignty' (1927) 13 Cornell Law Quarterly 8-30.

21 See B. Leiter 'Rethinking Legal Realism: Towards a Naturalized Jurisprudence' (1997-98) 76(2) Texas Law Review 267-315 at 272-273.

${ }^{22}$ See B. Leiter 'Rethinking Legal Realism: Towards a Naturalized Jurisprudence' (1997-98) 76(2) Texas Law Review 267-315 at 272-273.

${ }^{23}$ See B. Leiter 'Rethinking Legal Realism: Towards a Naturalized Jurisprudence' (1997-98) 76(2) Texas Law Review 267-315 at 273. 
realism lie within the realm of private law, legal realism is also germane to the public realm, it is just a matter of its application.

More recently the works of the legal realists have been reinterpreted by Leiter. Leiter argues that the dismissal and neglect of legal realism within Anglo-American jurisprudence can be attributed to Hart's devastating critique in Chapter VII of The Concept of Law $^{24}$ which rendered 'realism a philosophical joke in the Englishspeaking world'. ${ }^{25}$ Yet Hart, along with other legal philosophers, came to acknowledge $^{26}$ that they had misread the realists as offering a form of conceptual analysis, that is addressing the 'what is law' question. ${ }^{27}$ Leiter argues that the problem for legal realists is that of historicism. Legal realism came of an intellectual age in the heyday of positivism, the 1920's and 1930's, only to be dismissed in the 1950's and 1960s when naturalism became the dominant approach. According to Leiter, the American legal realists were philosophical naturalists who sought to

${ }^{24}$ H.L.A. Hart, Concept of Law (Oxford: Clarendon University Press, 1961).

${ }^{25}$ H.L.A. Hart, Concept of Law (Oxford: Clarendon University Press, 1961) pages $141-147$

26 See J.G. Murphy and J.L. Coleman, Philosophy of Law (Westview Press, 1989), pages 33-36.

27 See B. Leiter, 'Legal Realism' in D. Patterson (ed.) A Companion to the Philosophy of Law and Legal Theory (Blackwell: Oxford, 1996) pages 262-651; 'Rethinking Legal Realism: Towards a Naturalized Jurisprudence' (1997) 76(2) Texas Law Review 267-315.

27 See B. Leiter, 'Legal Realism' in D. Patterson (ed.) A Companion to the Philosophy of Law and Legal Theory (Blackwell: Oxford, 1996) page 264. 
address issues of adjudication rather than the 'what is law' question. ${ }^{28}$ The naturalist approach is not that of reflective contemplation of a phenomenon but seeks to subject the phenomenon to scientific inquiry. Accordingly, how judges reach a decision represents a phenomenon that merits scientific enquiry just as much as how judges ought to arrive at a decision. ${ }^{29}$ In many ways, Leiter provides the theoretical premise for legal realism that the realists sought to abandon along with the methodological parameters that Posner identified as being nonexistent.

\section{Scientific Realism}

Simplistically, scientific realism represents an approach to the interpretation of scientific theories and the perceptions or understandings relating to theoretical terms and claims. Scientific realists hold that there are objective facts which exist independent of any conceptual or theoretical framework. These facts do not have to be observed, in order for them to represent truth, but represent truths by virtue of their acknowledged existence which are determined by common sense and good reason. For example, a student will regard a recommended textbook as representing the truth even though the explanations and knowledge contained within the text book have not been observed or even tested by the student. Common sense and good reason justify the student's belief in the validity of the text book, after all, a lecturer would not

28 See B. Leiter, 'Legal Realism' in D. Patterson (ed.) A Companion to the Philosophy of Law and Legal Theory (Blackwell: Oxford, 1996), page 263. Also see B. Leiter, Naturalizing Jurisprudence (Oxford University Press: Oxford, 2007).

29 Generally see H. Kornblith, Naturalizing Epistemology $\left(2^{\text {nd }}\right.$ ed., MIT Press: Cambridge, Massachusetts, 1994). 
recommend a poor or inappropriate text book. In essence, scientific realism seeks to answer the question of how the success of science is to be explained without recourse to scientific method, that is by challenging the fallibility of scientific methods or the approximation of scientific knowledge.

It is acknowledged that there are many schools of scientific realism, such as naïve, critical, entity, truth, etc.. For the purposes of this paper it is not proposed to favour any particular form of scientific realism but to consider realism in terms of the construction of scientific theory. The justification for this approach being that the aim of this paper is to consider realism in the context of theory construction within public law rather than the validity or merit of any particular form of realism, be it scientific, legal or otherwise.

Within science there are numerous approaches to theory construction, namely instrumentalism, descriptivism, constructive and empiricism. Scientific realism represents an alternative to these approaches as its essence is that all scientific statements in scientific theories possess both truth and value. It is an approach that developed largely as a reaction to logical positivism where the essence of analysis is that of the distinction between theoretical terms and observational terms. Theoretical terms, unlike that of observational terms, are capable of semantic analysis in both their observational and logical form whereas observational terms represent observations and nothing else. There are however a number of problems with logical positivism which scientific realism sought to challenge.

For logical positivists the essence of scientific theory is the search for objectivity as the premise for explanation and description. The difficulty is in defining, identifying and even contextualising objectivity whether it be in terms of method, observation, semantics, theory or any other form. For scientific realists such 
a search for purity is unnecessary as theories are not just attempted explanations and descriptions of reality but go beyond that of directly observable entities to postulate theoretical entities which can result in predictions which are in themselves testable by observation. Scientific realism allows for the development of science by facilitating the construction of theory premised upon another theory whilst the approach of positivists inhibits such progression. Accordingly, the approach of scientific realism is one that accords with a key characteristic of scientific analysis, that of its selfcorrecting methodology. As a community, scientists attempt to solve cognitive problems by proposing hypothesis or constructing theories which are then tested by way of experimentation and observation. The published results are then examined by other scientists who can ignore them or choose to incorporate the material, either positively or negatively within their own research. Scientists do not test every facet which is incorporated within their analysis but accept that some analysis represents fundamental truths or background knowledge, such as the theories of evolution and gravity.

There are, of course, criticisms and critical alternatives to scientific realism. Critics of scientific realism argue that it is mistaken in that it does not matter which definition of truth is used as the outcome will always be the same. ${ }^{30}$ For example, a theory might provide a complete explanation of the whole truth of a particular phenomenon, but the theory could be applied to both the observed and unobserved,

30 See H. Putnam Reason, Truth and History (Cambridge: Cambridge University Press, 1981); B. Hale and C. Wright 'Putnam's Model-Theoretic Argument Against Metaphysical Realism' in B. Hale and C. Wright (eds.) A Companion to the Philosophy of Language (Oxford: Blackwell, 1997), pages 427-457. 
the real and the unreal. ${ }^{31}$ A critical alternative offered by social constructivists is that entities can exist in the same domain but are mind dependent in that they cannot exist beyond or without our construction of them, in other words truths are not discovered but are invented or constructed through organised social behaviour. ${ }^{32}$ Anti-realists deny that scientific theories refer to mind-independent unobservable entities. Instead, nothing exists outside of the mind and therefore theories should always be regarded as not representing the truth. ${ }^{33}$

Interestingly, just as legal realism has recently been re-evaluated so has scientific realism. Giere develops a version of realism arguing that scientific representations are like colours in that they only capture parts of reality. ${ }^{34}$ Furthermore, these perspectives of reality represent only bits of the world and will contain individual concepts and relationships inspired by religion or gendered

31 See R.N Giere Science Without Laws (University of Chicago Press: Chicago, 1999), pages 22-26.

32 Generally see R.N. Giere, Science Without Laws (University of Chicago Press: Chicago, 1999), pages 18-21.

33 Generally see M. Dummett, Truth and Other Enigmas (London: Duckworth, 1978).

34 R.N. Giere, Scientific Perspectivism (Chicago: University of Chicago Press, 2006). 
relations. ${ }^{35}$ For Giere, currently accepted scientific theories embody cultural values, a facet which inhibits their representational virtue. ${ }^{36}$

\section{Similarities between Legal Realism and Scientific Realism}

On the face of it, legal realism and scientific realism represent two very divergent forms of analysis yet it is possible to identify a rationale from which to test realism in public law along a number of notions for testing.

\section{The Rationale for Testing}

The rational for the testing of realism within public law analysis can be found in the works of Leiter and Giere. Leiter's re-evaluation of the legal realists provided a theoretical framework from which to test a body of analysis that was generally regarded as being atheoretical in nature. Conversely, the works of Loughlin, Walker and Allan already possesses a theoretical framework albeit one that is individuated rather than representing a collective approach to the theory of constitutionalism. The theoretical dimension is internal to public law indicating that there is an absence of an external dimension from which to test realism. It is this external dimension that Leiter brought to legal realism. This then raises the question, could not naturalism be

\footnotetext{
35 R.N. Giere, Science Without Laws (University of Chicago Press: Chicago, 1999), page 26.

36 R.N. Giere, Science Without Laws (University of Chicago Press: Chicago, 1999), page 26.
} 
used to test the works of Walker, Loughlin and Allan? It is suggested that it could not.

At the heart of naturalism is the requirement that phenomenon must be amenable to empirical inquiry. It is a philosophical theory that seeks to draw on scientific methodologies and it this feature which makes the theory amenable to legal realism. As Leiter argues, the legal realists were essentially offering a descriptive theory of adjudication, that it is what judges really do when they decide cases. ${ }^{37}$ The theory of constitutionalism is not a theory of adjudication. It is also not a descriptive theory although it may possess descriptive elements and finally, it is not a phenomenon that lends itself to empirical inquiry although facets of it could be empirically tested. For these reasons constitutionalism is not amenable to naturalism. So, whilst it may not be feasible to adopt Lieter's choice of theory it may be possible to adopt his approach, that of deploying a scientific paradigm for the testing of realism within public law.

Giere's analysis discussed above indicated that it was possible to view the world through the spectrum of colours. ${ }^{38}$ The spectrum of colours that human beings can see possesses a definitive structure known as the 'hue circle'. The hue circle is a contained circle which incorporates the four unitary hues of red, green, blue and yellow but also accommodates variations of these unitary hues in terms of intensity and brightness. The fact that the model is circular rather than linear means that there

\footnotetext{
37 B. Leiter, Naturalizing Jurisprudence (Oxford University Press: Oxford, 2007), page 60 .

38 R.N. Giere, Scientific Perspectivism (Chicago: University of Chicago Press, 2006), pages 17-18.
} 
is no simple or direct linear relationship between colour and wavelength. ${ }^{39}$ In other words, the circular model facilitates a connection of variations that are excluded along with variations that a linear model could never achieve. Not only can connections be made with neighbouring colours there is the potential to connect within colour variations that are diametrically opposed. Giere also argues that a further advantage of the model is that it allows for perspectivism, the inclusion of colour subjectivism and colour objectivism. ${ }^{40}$ The spectrum, for example, not only takes into account the variations of the human visual system, such as the objective facets of colour but also subjective variations of colours, such as those induced by synthesis. ${ }^{41}$ It also allows for comparison beyond the human. Just as humans have a colour perspective of the world, so do cats, dogs, fish, monkeys and birds. ${ }^{42}$ These perspectives are different for a variety of reasons but still represent a coloured perspective and one that can be used to learn about differing perspectives. ${ }^{43}$ Could not the varying works of Walker, Loughlin and Allan be represented as varying points on the spectrum of constitutionalism with each theorist capturing a particular facet of reality?

39 R.N. Giere, Scientific Perspectivism (Chicago: University of Chicago Press, 2006), page 18 .

40 R.N. Giere, Scientific Perspectivism (Chicago: University of Chicago Press, 2006), page 32 .

41 R.N. Giere, Scientific Perspectivism (Chicago: University of Chicago Press, 2006), page 32 .

42 R.N. Giere, Scientific Perspectivism (Chicago: University of Chicago Press, 2006), page 32 .

43 R.N. Giere, Scientific Perspectivism (Chicago: University of Chicago Press, 2006), page 32 . 


\section{The Basis of Testing}

Whilst difference, in terms of legal realism and scientific realism, provided the rationale for testing, it is the similarities that will provide the basis for the testing of realism in public law.

Firstly, both forms of realism indicate that within law and science there exists a 'local belief system'. Beliefs are local in that both law and science possess views of their own domain. These beliefs are also systematic in that each domain determines

the legitimate methods by which knowledge can be acquired within each realm. ${ }^{44}$ For example, within law the common law system represents a fundamental method by which knowledge is acquired, developed and explained.

Secondly realism, be it legal or scientific, indicates that each belief system possesses its own boundaries within which knowledge exists and can be acquired. Sometimes the beliefs of each local system can be shared with other domains, such as philosophy or political theory, but there is also the potential for conflict, for example, religion or sociology. Ultimately this suggests that the boundaries of each system are flexible, porous and possibly even flawed. This challenge stems from the perception that there are unexplained or unincorporated facets which are currently excluded from the established boundaries of analysis yet these facets are essential for the development of analysis. Without this material analysis may advance but such advancement will ultimately be inhibited by virtue of the self-defined boundaries. As scientific realists assert, without the unchallenged acceptance of some forms of

44 Generally see I. Niinilouto, Critical Scientific Realism (Oxford: Oxford University Press, 1999), page 5. 
scientific understanding, such as Newtonian mechanics, how else could man land on the moon.

Thirdly, the essence of the challenge for realists, both legal and scientific, is the exclusion of essential facts for the development of their analysis, that is 'common sense'. Common sense is never completely defined but is represented as indicating materials which, on the face of it, merit inclusion because of their prima facie practicalness. In other words, rather than looking at the world through the court room or the microscope the world should be gazed upon outside of these mediums.

Finally, the above similarities indicate that there are semantic, methodological and ontological similarities between legal realism and scientific realisms. Accordingly, it is proposed to focus on these three facets when critiquing realism in respect of the public lawyers, works of Walker, Loughlin and Allan.

\section{Key Features of Realism and Public Law Analysis}

\section{Ontological Considerations}

Simplistically, ontological considerations relate to the nature of reality. For legal realists the nature of legal reality is that it is unrealistic, too removed from actuality, whilst for scientific realists the issue is that of testing for reality, determining which entities represent reality and which do not. In ontological terms both legal realists and scientific realists are concerned with the determinacy of reality. Where they may differ is on where to look for reality, a matter of methodology. A concern with the determinacy of reality is a facet that can found in the works of the theorists. 
For Loughlin the determinability of realism within public law centres upon his understanding of the notions of the state and power. The state is represented as being composed of staatsgebeit, staatsgewalt, and staatsvolk ${ }^{45}$ which 'gives us access to the nature of modern political reality and provides the key to understanding public law' ${ }^{46}$ In respect of power the focus of analysis is the relationship between the constituent authority and constituted power. ${ }^{47}$ This understanding of the individual state is replicated throughout the entire world which is now divided into an assortment of sovereign states. ${ }^{48}$ The internal functioning of these states, and the relationship between authority and power that they contain, is governed by the pure theory of public law, ${ }^{49}$ which understands public law as an 'autonomous subject ${ }^{, 50}$ made up of 'an assemblage of rules, principles, canons, maxims, customs, usages, and manners' ${ }^{51}$ that condition and maintain the 'activity of governing. ${ }^{52}$

${ }^{45}$ M. Loughlin, 'In Defence of Staatslehre' (2009) 48(1) Der Staat 1-28 at 6.

${ }^{46}$ M. Loughlin, 'In Defence of Staatslehre' (2009) 48(1) Der Staat 1-28 at 8.

47 M. Loughlin, The Idea of Public Law (Oxford: Oxford University Press, 2003), page 160 , precept 26 .

${ }^{48}$ M. Loughlin, The Foundations of Public Law (Oxford: Oxford University Press, 2010), page 2 .

49 M. Loughlin, The Idea of Public Law (Oxford: Oxford University Press, 2003), Chapter 9 specifically outlines the precepts of the pure theory, though the book as a whole provides the necessary foundation for understanding the theory.

50 M. Loughlin, The Idea of Public Law (Oxford: Oxford University Press, 2003), page 153 .

51 M. Loughlin, The Idea of Public Law (Oxford: Oxford University Press, 2003), page 132 . 
For Walker, the determinability of realism goes beyond that of the state and is to be found in multiple other sites of authority, at a variety of levels, all of which are plausible sites of authority to differing degrees. ${ }^{53}$ Walker also acknowledges a plurality of understandings of the idea of constitutionalism, and believes that a realistic appraisal of the present context must find some way of accommodating these many 'frames' of constitutionalism convincingly. ${ }^{54}$ This entails finding a place for statist constitutionalism, whilst simultaneously accommodating alternative conceptions which will require the traversing of not-insignificant linguistic obstacles. $^{55}$

Allan's perceptions on the nature of reality is that it is based on the appropriately reconciled relationship between the courts and parliament as supreme law-making and law-defining bodies along with the resulting connections between the interpretation of statutes and their implementation within case law. ${ }^{56}$ According to

52 M. Loughlin, The Idea of Public Law (Oxford: Oxford University Press, 2003), page 30 .

53 N. Walker, 'Late Sovereignty in the European Union' in N. Walker, Sovereignty in Transition (Oxford: Hart Publishing, 2003), page 4.

54 Most recently outlined in N. Walker, 'Beyond the Holistic Constitution?' in P. Dobner and M. Loughlin (eds.) The Twilight of Constitutionalism? (Oxford: Oxford University Press, 2010), Chapter 14.

55 N. Walker, 'Postnational Constitutionalism and the Problem of Translation' in J.H.H. Weiler and M. Wind (eds.) European Constitutionalism Beyond the State (Cambridge: Cambridge University Press, 2003).

56 T.R.S. Allan, Constitutional Justice: A Liberal Theory of the Rule of Law (Oxford: Oxford University Press, 2001), page 3. 
Allan, only this constructivist interpretative approach allows a general rule's application in a particular case to be 'fitted into the complex tapestry of the law', ${ }^{57}$ and therefore provide an understanding of the nature of the entirety of law, and in particular public law's constitutionalism. Statutory changes to the fabric of constitutionalism can only find their true elaboration 'within the wider legal order they seek to modify'. ${ }^{58}$ All public law constitutionalism must be understood, according to Allan, in light of the 'enduring constitutional precept ${ }^{59}$ of the rule of law and principles of justice, as enacted by the imagined 'conscientious legislator'. ${ }^{60}$ For Allan constitutional reality is founded and resides solely in the common law tradition. Having identified the diverse ontological considerations of the theorists it is proposed to examine these in terms of the key features of legal realism and scientific realism as identified above, that of beliefs, boundaries and common sense. Beliefs as to the determinacy of reality lie in terms of the notions essential for the development of analysis. For Loughlin these are the abstract notions of the state and power, whilst for Walker it is the contextual non-statist organisations and multiple centres of power. For Allan it is the practicality of the common law but juxtaposed against theory, the rule of law. Boundary in ontological terms is not so much what they are but a matter

57 T.R.S. Allan, Constitutional Justice: A Liberal Theory of the Rule of Law (Oxford: Oxford University Press, 2001), page 14.

58 T.R.S. Allan, Legislative Supremacy and Legislative Intention: Interpretation, Meaning and Authority' (2004) 63(3) Cambridge Law Journal 685-711 at 689.

59 T.R.S. Allan, 'Legislative Supremacy and Legislative Intention: Interpretation, Meaning and Authority' (2004) 63(3) Cambridge Law Journal 685-711 at 690.

60 T.R.S. Allan, 'Legislative Supremacy and Legislative Intention: Interpretation, Meaning and Authority’ (2004) 63(3) Cambridge Law Journal 685-711 at 690. 
of what they are not. For Loughlin, the true nature of public law and the theory of constitutionalism does not lie within law alone but must include aspects of the nonlegal. The nature of the boundary is that it must not exist for reality to be seen. The true issue is essentially a matter of methodology. Although the choice of method can represent a form of ontological boundary in that the method used will place limits on the analysis. For Walker, the true nature of constitutionalism is about extending the range of institutions and centres for decision making. Like Loughlin, the matter of boundary is that it must not exist. The core issue is one of structure, although the choice of structure, like that of methodology can also represent a form of boundary in that it will also place limits on the analysis. For Allan, there is a clearly defined ontological boundary, that of law, although Allan does seek to widen the sources within that boundary to include not just case law but also theory, albeit legal theory. In some respects it is a matter of structure, akin to that of Walker, except that Allan's structure is internally defined, a matter of depth as opposed to Walker's search for external breadth. In terms of the feature of common sense, for Loughlin this lies in the absurdity of not incorporating the political or historical. Public law does not exist in a vacuum so how else can the true nature of the theory of public law be identified? For Walker common sense lies in the recognition of the contemporary world and the multitude of agents involved in governing, whilst for Allan common sense is to be found in the common law, the product of reasoned decision making.

\section{Methodological Considerations}

Methodology is about how information relating to a particular phenomenon is acquired. For legal realists information about law is to be found by looking beyond 
the decision making of the courts, particularly judge made incremental case law to consider how the law is applied in the actual world. For scientific realists information is acquired by moving forward, testing new knowledge rather than retesting past knowledge. There is an acceptance that theoretical entities of mature scientific theories really do exist and that the explanation offered by the theory in respect of phenomena are sufficiently accurate or truthful. In terms of method both legal realists and scientific realists seek to 'leave the past behind' and look to the future which includes examining the external and even the peripheral.

In respect of the theorists, Loughlin's methodology is to draw upon the historical, political and philosophical. It is suggested that the choice of method is a direct consequence of the theories that Loughlin seeks to promote, that of constitutionalism, but more particularly, a specific theory of public law. Public law is a 'young' area of law when contrasted with contract or trusts. ${ }^{61}$ Loughlin's concern,

${ }^{61}$ Constitutional issues have a 'pedigree' of scholarly study amongst historians as evidenced by the works of W. Stubbs, The Constitutional History of England in its Origin and Development (1874-8); E.A. Freeman, The Growth of the English constitution form the earliest times (1876); T.B. Maccauly, History of England (1876) and H. Hallam, Constitutional History of England (1848). These works are generally viewed as representing a 'whig interpretation of history' where there is an inevitable progression towards liberty culminating in democracy and a constitutional monarchy (See H. Butterfield, The Whig Interpretation of History, 1931). It is only in the late $19^{\mathrm{TH}}$ century that law professors with a specific interest in constitutional issues emerged, most notably, A.V. Dicey. Dicey's Introduction to the Study of the Law of the Constitution (1885) established constitutional issues as a legitimate area of interest to lawyers and not a subject exclusive to historians. In contrast, contract and trusts, 
and hence his choice of methodology, is the control of the exercise of political (public) power. Given the absence, within the UK's constitutional arrangements, of a definitive and structured framework, for the exercise of power, such as that of a state, Loughlin turns to the theory of constitutionalism as a possible explanation and a framework for his theory of public law. The advantage of the theory of constitutionalism is that it does provide a normative and valuative basis from which to critique the exercise of power in a constitutional framework. The disadvantage is that it is a theory which originates within the USA and is therefore premised on the existence of a written constitution. ${ }^{62}$ Its transition to the UK has not been immediate and has been the subject of much critique. ${ }^{63}$ Loughlin addresses this 'problem' of translation by way of his methodology. He draws upon historical, political and philosophical paradigms within which facets of constitutionalism can be identified, in particular the need to define, limit and structure power, indicating a preference for

have always represented legitimate areas of interest to lawyers. The struggle here, and one relevant to others areas of law, was the establishment of academic credibility and legitimacy. See D. Sugarman 'Legal Theory, the Common Law Mind and the Making of the Textbook Tradition' in W.L. Twining (ed.) Legal Theory and Common Law (Oxford: Blackwells, 1986) pages 26-61.

62 See L.A. Alexander, Constitutionalism: Philosophical Foundations (Cambridge; New York: Cambridge University Press, 1998).

63 For example H.H. Weiler and M. Wind (eds.) European Constitutionalism Beyond the State (Cambridge: Cambridge University Press, 2003); P. Dobner and M. Loughlin (eds.) The Twilight of Constitutionalism? (Oxford: Oxford University Press, 2010). 
republican constitutionalism rather than its liberal-legal counterpart. ${ }^{64}$ Once these paradigms are identified Loughlin proceeds to construct a theory of the state resulting in the ultimate construction, that of a theory of public law.

Walker, until recently, focused his analysis on the 'realties' of the practical decision making of governments and governmental agencies. Walker seeks to ground his analysis of constitutionalism and the state at the actual face of decision making. It represents an effort to capture and construct the functioning of reality by fashioning an observation based theory of constitutionalism which encapsulates the complex workings of the global order.

Allan adopts a similar methodology to that of Walker, albeit in a different form. Allan also seeks to understand the operation of constitutionalism at the implementation and adjudicatory levels but does not consider the agents involved in such decision making, the outcomes that flow from these levels. The focus is on the substantive aspects rather than the procedural concerns of Walker but ultimately their goals are the same, the moving forward of legal analysis rather than an explanation of where current legal analysis has come from.

Having identified the diverse methodological approaches of the theorists it is proposed to examine these in terms of the key feature of legal realism and scientific realism as identified above, that of beliefs/premises, boundaries and common sense. All the theorists deploy their methodology from a particular belief or premise. For Loughlin it is the premise that the present can only be understood by reference to the past, for Walker and Allan it is the flawed paradigms within which current analysis is

${ }^{64}$ M. Loughlin, "What is Constitutionalisation?' in P. Dobner and M. Loughlin (eds.) The Twilight of Constitutionalism? (Oxford: Oxford University Press, 2010) pages 61 and 64-66. 
conducted that must be challenged. There are also methodological boundaries than can be identified. For Loughlin the goal is to challenge the established methodological boundaries of public law by including the historical, political and philosophical. Walker and Allan also seek to challenge boundaries but do so in differing ways. For Walker the challenge is about widening boundaries in terms of the range of institutions involved in making decision of a constitutional nature but also a stretching the range of decisions that can be viewed as belonging to the constitutional order. ${ }^{65}$ Allan's challenge relates to the re-ordering of existing methodological premises from which constitutional analysis is conducted. Allan accepts that case law and theory are the correct premises for constitutional analysis, therefore the boundary remains intact. Yet, instead of common law, in the form of judge made decision making, providing the sole basis for constitutional analysis, such decisions should be tempered in accordance with theory, in particular, the rule of law. In terms of methodology and boundary analysis it is interesting to note the consequences of such analysis. For example, it could be argued that all three theorists attempt to move beyond the traditional two-dimensional analysis that dominates public law to construct three-dimensional models. Loughlin's three-dimensional model incorporates the traditional hierarchal structures but includes a re-evaluation of the notions of the state and sovereignty (the basis for the exercise of relational power) but expands his re-evaluation of this traditional two-dimensional model by incorporating a new, third dimension, that of the relationship of the present to the past. For Walker, the traditional hierarchal structures remain but there is an

65 N. Walker 'Constitutionalism and the Incompleteness of Democracy: An Iterative Relationship' (2010) 39(3) Rechtsfilosofie \& Rechtstheorie 206-233 at 223224. 
expansion of the range of institutions to be included thereby creating a more diverse arrangement. Such an expansion can be represented as being in terms of the breadth of material to be incorporated within any analysis of constitutionalism but it also represents an expansion in terms of time. For Loughlin, the dimension of time relates to looking to the past, for Walker it is about looking to the present with the presumption that it also represents the path for future analysis. Ironically, the same pattern can be identified in respect of Allan although it yields different results. There is hierarchy in terms of institutions along with breadth in terms of whether values or theory should form the basis of analysis. The reordering of the relationship of theory and values does however represent the emergence of a third dimension, that of time. Judicial decision making does not exist in a vacuum and if public law analysis is to move forward it must recognise the relationship between theory and values.

Common sense for Loughlin stems from the premise that the state is a key, unique and powerful institution within contemporary public law analysis. Common sense therefore dictates that to understand how such power is exercised it is necessary to look to the past, in particular, the historical and political paradigms which provide the justifications and premises for the exercise of state authority. For Walker, common sense relates to the need to expand the range of institutions and the range of their decision making. The vacuum of current analysis relates to the present whilst for Loughlin the vacuum is that of the absence of inclusion of the past. For Allan, common sense is just as practical as that of Loughlin and Walker but it is about the reordering of what there is rather than what must be included.

Semantic Considerations 
Semantic considerations relate to the relationship between language and reality, that is meanings assigned to notions and terms used to explain reality and the style of construction. In respect of legal realists, the challenge to the relationship between language and reality lies in their attack upon the use of case law, precedent, statutory interpretation, etc.. The use of such terms are a mere pretence to hide the factors which actually influence judicial decision making. For example, if parties to a commercial transaction view that it is binding then it is irrelevant that such an agreement does not fit the traditional 'black letter' definition of a contract. ${ }^{66}$ For scientific realists, semantic considerations can be simplistically explained as the understanding that theories, models and concepts (the terms used to explain reality) are truthful. The approach represents the converse of legal realists but there is a common feature, that of truthfulness. It is just the path to truthfulness which differs. In terms of Walker, Loughlin and Allan it is possible to identify facets of truthfulness. For example, Walker's early analysis on constitutionalism focused on the 'range of different constitutional sites and processes configured in a heterarchical rather than a hierarchical pattern'. ${ }^{67}$ Walker later argues that the only way to construct a theory capable of comprehending the plurality of 'constitutionalisms' is to 'proceed at a very high level of abstraction', even a 'rarified level'. ${ }^{68}$ He also notes that the problems of

66 See K.N. Llewellyn, 'A Realistic Jurisprudence - The Next Step' (1930) 30 Columbia Law Review 431-465 at 438-43, 447-53.

${ }^{67}$ N. Walker, 'The Idea of Constitutional Pluralism' (2002) 65(3) The Modern Law Review $317-359$ at 317.

68 N. Walker, 'Beyond the Holistic Constitution?' in P. Dobner and M. Loughlin (eds.) The Twilight of Constitutionalism? (Oxford: Oxford University Press, 2010), page 296. 
translating linguistic meanings and contexts from one tradition of constitutionalism into another are not easily achieved ${ }^{69}$ but does suggest a rudimentary value-led framework for the translation. ${ }^{70}$ This has subsequently been complemented by an examination of the values of constitutionalism and democracy and their iterative relationship. ${ }^{71}$ Walker's search for truthfulness entails a distillation of the meaning of constitutionalism at both state and non-state levels with a resulting compromise on the meanings of the core values of constitutionalism in order to achieve a consensus. Walker's approach possesses similarity with that of the legal realists, the challenging of existing linguistic terminology in order to identify the truth, but the outcome is a reification of key notions and the construction of a theory of constitutionalism that could achieve the status of a scientific theory in terms of its truthfulness. In terms of semantic considerations of realism, Walker's approach combines elements of both legal and scientific realism.

For Loughlin there is also a similar setting aside of existing terms and concepts but also the abandonment of established methodology. The focus is on a critical re-evaluation or interpretation of key notions within public law, such as sovereignty and power but also the introduction of concepts that are unfamiliar in the

69 N. Walker, 'Postnational Constitutionalism and the Problem of Translation' in J.H.H. Weiler and M. Wind (eds.) European Constitutionalism Beyond the State (Cambridge: Cambridge University Press, 2003), page 32.

70 N. Walker, 'Postnational Constitutionalism and the Problem of Translation' in J.H.H. Weiler and M. Wind (eds.) European Constitutionalism Beyond the State (Cambridge: Cambridge University Press, 2003), pages 45-52.

71 N.Walker 'Constitutionalism and the Incompleteness of Democracy: An Iterative Relationship' (2010) 39(3) Rechtsfilosofie \& Rechtstheorie 206-233. 
context of British public law. Specifically, these are the ideas of public law as droit politique, ${ }^{72}$ a particular theory of state ${ }^{73}$ and the pure theory of public law. ${ }^{74}$ Loughlin is, however, keen to emphasise early on that public law is a "universal phenomenon" ${ }^{75}$ and thus his discourse is not limited to a single state context. As Walker noted in relation to his own work, the importation of alien notions from one discourse tradition to another is likely to result in either confusion, misinterpretation, or both. ${ }^{76}$ Loughlin himself admits that in the UK 'we lack the vocabulary for distinguishing between law as an instrument of government (lex, la loi, das Gesetz) and law as an expression of the constitutive principles of right-ordering (ius, le droit, das Recht).$^{77}$ Loughlin's approach is therefore more in accordance with legal realist than scientific realists.

Allan, in contrast to Walker and Loughlin, firmly retains the traditional language of public lawyers and constitutionalism. Allan's view is that all laws and legal theory must be understood within the framework of knowledge they hope to alter because 'in

72 The whole of the Foundations of Public Law is an explication of droit politique as the basis of public law.

73 Most succinctly encapsulated in M. Loughlin, 'In Defence of Staatslehre' (2009) 48(1) Der Staat 1-28 and expanded upon more broadly in M. Loughlin, Foundations of Public Law (Oxford: Oxford University Press, 2010), particularly in chapters 7,8 and 9 .

${ }^{74}$ M. Loughlin, The Idea of Public Law (Oxford: Oxford University Press, 2003).

75 M. Loughlin, Foundations of Public Law (Oxford: OUP, 2010), page 2.

76 N. Walker 'Postnational Constitutionalism and the Problem of translation' in J.H.H. Weiler and M. Wind (eds.), European Constitutionalism Beyond the State (Cambridge: Cambridge University Press, 2003), pages 41-42.

77 M. Loughlin, Foundations of Public Law (Oxford: OUP, 2010), pages 8-9. 
the real world laws must be understood and applied in the context of existing tradition and reasonable assumption'. ${ }^{78}$ Allan's approach certainly does not accord with that of legal realists but it does possess some similarity with that of scientific realism in that there is an acceptance of the truthfulness of the current language of law, that of case law.

Again, it is proposed to examine approaches of the theorists in terms of beliefs/premises, boundaries and common sense. The premises from which Loughlin and Walker begin their analysis is that the current language of public law and constitutionalism is inadequate. ${ }^{79}$ For Loughlin this results in the re-interpretation of some exiting concepts and the inclusion of concepts that are unfamiliar. Walker accepts existing definitions but seeks to widen their scope. Inherent within both approaches is the assumption that meanings, which exist within one realm, can be transferred to another. Allan's analysis is premised on the acceptance of existing terminology. In terms of realistic analysis and premise/belief, the approach of Walker and Loughlin accords more with that of legal realists whist Allan's favours that of scientific realism, the acceptance of the truthfulness of existing terms. In terms of boundary analysis it can be argued that Loughlin's approach is the most challenging

78 T.R.S. Allan, 'The Constitutional Foundations of Judicial Review: Conceptual Conundrum or Interpretative Inquiry?' (2002) 61(1) Cambridge Law Journal 87- 125 at 104 .

79 See this continuing in N. Walker 'Constitutionalism and the Incompleteness of Democracy: An Iterative Relationship' (2010) 39(3) Rechtsfilosofie \& Rechtstheorie 206-233 and M. Loughlin 'What is Constitutionalisation' in P. Dobner and M. Loughlin (eds.) The Twilight of Constitutionalism? (Oxford: Oxford University Press, 2010) pages 47-69. 
and original whilst Walker and Allan are content with the boundaries of exiting terminology. Their challenges to the semantics of constitutionalism are, however, quite different. Walker seeks breadth in terms of existing terminology, the range of institutions, whilst Allan seeks depth, the use of theory. Allan does not acknowledge or accept that there is a definitional or conceptual crisis in terms of the theory of constitutionalism. There are, of course advantages to Allan's approach in that by viewing the debate on constitutionalism as a matter of 'locality', that is the existing parameters of public law analysis. Allan does not need to consider or critique the conceptual and global hurdles that Loughlin and Walker seek to address. The disadvantage is that of the extent or degree of the truthfulness of Allan analysis. The presumption is that the existing parameters of analysis, that of the common law, represents the truth but the reality of such truthfulness needs to be accentuated by the incorporation of theory. This would indicate that the premise from which Allan's analysis commences represents the truth but semantic considerations require it to be accentuated so that its actual truthfulness can be recognised.

Finally, the notion of common sense can be found in respect of all the theorists. For Loughlin, if current notions are inadequate then it represents common sense to re-define or re-interpret or include new notions to explain reality. This approach, it could be argued, stems from Loughlin's functionalist origins and normative preferences. For Walker and Allan, common sense is about the re-ordering of existing terms to reflect reality or to have a perception of reality become more apparent.

\section{Summary}


The above exploration affirms and reinforces the diversity of analysis that the writings of Walker, Loughlin and Allan represent in terms of the theory of constitutionalism. It is suggested that the arguments identified can be placed into two categories, that of the tangibility of realism and the configuration of realism.

Walker and Allan argue that existing perceptions of constitutional governance are tangible, yet their perceptions of tangibility differ. For Walker tangibility is premised on a multi-layered and multi-faceted perspective whilst for Allan, tangibility is premised on the common law which is manifested through established institutions of parliament, the courts but also theory, in particular, the rule of law. Conversely, Loughlin asserts that current public law analysis is premised on intangibility, in particular, the inadequacy and inaccuracy of current public law analysis to evaluate the realities of contemporary constitutionalism.

Such diverse approaches in respect of tangibility bring with them divergent approaches in terms of reconfiguration, that is how public law analysis in relation to the theory constitutionalism can be made to be real or more realistic. Loughlin's solution is that of historicism, to search through the past in order to explain the foundation for the present. Conversely, Walker and Allan argue that reconfiguration relates to the present, that of widening the parameters of analysis in terms of the institutional or theoretical, which can be represented as that of breadth and depth. Accordingly, it can be concluded that no one particular analysis represents reality or is more real or less real than the any other analysis. All that can be concluded is that there is difference but also similarity. Such a conclusion could be represented as a non-conclusion except that it is a conclusion, which accords with Giere's 'hue circle' model and its capacity to incorporate both individual and collective perceptions of reality. 


\section{The 'Hue Circle' and Reality in Public Law Analysis}

The example offered by Giere in order to demonstrate the facilitative nature of the 'hue circle' is that of the rug. ${ }^{80}$ To the person with normal human vision they will see the rug in terms of the unitary hues of red, green blue and yellow along with its variations whilst the person who possesses partial colour vision or is colour blind will see the rug in a different way, omitting some colours or emphasising others. The perspectives of those with partial colour vision or colour blindness are not wrong, nor are they conflicting, they are just different. Even the perspective of the person with normal human vision is not real because it will omit the perspective of those who are colour blind or possess partial colour vision. Giere argues that all such differences are compatible because they all draw upon the colours contained within the hue circle. They just do so in varying ways by drawing upon varieties of hue and brightness.

Drawing upon Giere's analysis it can be argued that the individual perceptions of Allan, Loughlin and Walker represent dissimilar visions of the theory of constitutionalism, akin to that of Giere's analogy of the rug. The existence of these varying perceptions does not indicate that one particular theorist is more real, true or false than another, just that they are different. In other words difference is acceptable and does not undermine or invalidate alternative representations in terms of the theory of constitutionalism.

There are a number of outcomes to be found in respect of adopting the hue circle model. There is, for example, the identification of new and diverse ways of

80 R.N. Giere, Scientific Perspectivism (Chicago: University of Chicago Press, 2006), page 33. 
examining the theory of constitutionalism, the constitutional arrangements of the UK and its wider setting in the global world. Loughlin enables public lawyers to become familiar with the language and vocabulary of political theory and acquire an understanding of historical methodology. Walker's analysis provides the potential to incorporate the global and multifaceted layers of decision making. When contrasted with such expansive contributions to the theory of constitutionalism Allan's analysis may appear to be the most unimaginative, irrelevant or even the least dynamic. Yet, it is argued, what Allan does offer may be the most significant in terms of the long term development of the theory of constitutionalism within public law and public law analysis in general. Allan's approach allows for introspection, that is, the ability to offer an internal examination and critique, albeit within prescriptive boundaries. Such internal reflection is essential for the development of any analysis.

\section{Conclusion}

The goal of this paper was to offer an exploration of assertions of realism within public law analysis. Given the extensiveness of such a remit it was proposed to focus exclusively upon three esteemed public lawyers, Walker, Loughlin and Allan and one particular area of public law analysis, that of constitutionalism. The outcome of the paper is that no single representation by the theorists or the combined manifestation of their analysis reveals a conclusive or all-encompassing revelation of what represents 'reality' within public law. Ironically, this absence of a definitive conclusion has not prevented the construction of a perception of realism within public law analysis. By deploying Giere's model of perspectival realism onto constitutionalism it became possible to incorporate the analysis of all three theorists on an individual and 
collective level. This outcome has numerous consequences in terms of the theory of constitutionalism in particular and public law analysis in general.

Firstly, the model allows for the accommodation of the depth and breadth of variations on constitutionalism identified in respect of the three theorists. Connections between the theorists can also be made more directly and readily. Secondly, the model does not allow for the dismissal or invalidation of assertions of realism by any of the theorists as the model accepts that all assertions of realism represent reality. In terms of the three theorists this allows for the accommodation of all methodological, ontological and semantic differences identified above. The attraction of such an approach is that differences do not represent unreality but are variations of reality. Finally, the model allows for the further development of the theory of constitutionalism on one level but also public law analysis on another level. In terms of the theory of constitutionalism, there is the possibility to include material that does not currently appear, such as feminist critiques, material which may be viewed as being unrealistic. Accordingly, if such a model can accommodate breadth and depth in one particular area of public law could it not be used within other areas of public law analysis? 